\title{
Debata: Po co nam prawa alowieka?
}

\section{Moderator: dr Piotr W. Juchacl \\ Elssperi: dr Karolina M. Cern, dr Andrejej. Nowak, dr Krnystoo Pryzbyszewski Ucestnicy: Mlodiziei l gimnaziów ilicéw z Ponnania i Wiellopolski}

\section{Debate: Why do we need human rights?}

Abstrut: The debate Why do we need human rights? took place on April 10th, 2013 at the Faculty of Social Sciences, Adam Mickiewicz University in Poznań. It was a part of the conference Philosophy is changing the world! organized under the auspices of Public Philosophy \& Democratic Education journal. The participants of the debate were the youth from middle and high schools in Poznan and Greater Poland and invited experts from the Institute of Philosophy, AMU: Dr. Karolina M. Cern, Dr. Andrzej W. Nowak, Dr. Krzysztof Przybyszewski. Discussion was moderated by Dr. Piotr W. Juchacz. Youth was asking, inter alia, about what human rights are and how freedom is understood within human rights; whether human rights are associated with the European culture or have universal character; whether international documents relating to human rights are fully respected in Poland; and whether attempts at restricting the access to certain content on the Internet is a violation of human rights.

Keywords: human rights, freedom of expression, particularism vs universalism of human rights;

Debata odbyła się 10 kwietnia 2013 roku na terenie Wydziału Nauk Społecznych Uniwersytetu im. Adama Mickiewicza w Poznaniu i stanowiła część konferencji Filozofia zmienia świat! zorganizowanej pod patronatem czasopisma Filozofia Publiczna i Edukacja Demokratyczna w ramach XVI Poznańskiego Festiwalu Nauki i Sztuki. 
Dr Piotr W. Juchacz

Szanowni Państwo, bardzo miło mi Was powitać na debacie zatytułowanej „Po co nam prawa człowieka?”. Nasze spotkanie stanowi druga cześć konferencji Filozofia zmienia świat! odbywającej się w ramach XIV Poznańskiego Festiwalu Nauki i Sztuki. Naszymi ekspertami w trakcie dzisiejszej debaty będą pracownicy Instytutu Filozofii UAM, Pani dr Karolina Cern, która specjalizuje się w etyce i filozofii prawa, oraz Panowie dr Andrzej Nowak i dr Krzysztof Przybyszewski zajmujący się filozofią społeczną i polityczna. Zgodnie z przyjętą formuła dyskusji nasi eksperci są do Państwa dyspozycji, proszę o zadawanie pytań.

\section{Pytanie nr 1}

\section{Co to są prawa czlowieka?}

\section{Dr Karolina M. Cern}

Szanowni Państwo, wydaje mi się, iż są Państwo właśnie w tym wieku, w którym Państwa świadomość się wyodrębnia i indywidualizuje. Podczas tego procesu zadajecie sobie zapewne pytania: Czy rzeczywiście muszę lub powinnam/powinienem robić to, czego rodzice bądź nauczyciele ode mnie chcą? Czy muszę lub powinnam/powinienem spełniać oczekiwania innych? Dlaczego? A może posiadam pewne uprawnienia do tego, aby o pewnych kwestiach związanych z moją osobą i życiem autonomicznie decydować? Innymi słowy, są Państwo w tym okresie, w którym w sposób niemalże „naturalny” zadaja Państwo pytania o uzasadnienie rozmaitych roszczeń związanych z powinnością czy obowiązkiem, a wysuwanych pod Państwa adresem ze strony rodziny, przyjaciół, a także nauczycieli lub innych osób funkcjonujących w sferze publicznej. Pojawiają się pytania o uzasadnienie roszczeń normatywnych, czyli roszczeń dotyczących, z jednej strony, tego, co i jak powinno się czynić a czego nie powinno się, nie można czynić, a z drugiej strony, dotyczących tego, co można czynić i do czego się ma prawo. Jakie sa podstawy bądź kryteria dobrze sformułowanych uzasadnień? To znaczy: czy mam prawo decydować o tym-i-tamtym, gdyż jestem w takim ,już” wieku, albo mam „taką właśnie” płeć, lub pochodzę z jakiegoś określonego miasta bądź kraju, lub zdobyłam/zdobyłem już takie oto wykształcenie? 


\section{8 | Debata |}

A może nie mam prawa decydować o czymś właśnie dlatego, że jestem innej płci, wyznania, koloru skóry lub po prostu pochodzę z innego miasta, kraju, kultury?

Szanowni Państwo, uzasadnienia mogą być różne, zależne od wagi oraz zasięgu roszczeń normatywnych wysuwanych pod naszym adresem, ale też częstokroć wysuwanych przez nas pod adresem innych. $\mathrm{O}$ tyle bowiem X-ski ma uprawnienia, o ile Y-ski ma związane z ich realizacją obowiązki i vice versa. Istotne tutaj jest jednak to, iż zastanawiając się nad możliwymi uzasadnieniami powinności czy obowiąków oraz uprawnień i praw, wykraczamy w tych rozważaniach poza to, co nas otacza - poza Polskę, Europę etc. - i zastanawiamy się czy gdybyśmy żyli w jakimś innym miejscu, w innym środowisku, to czy te oczekiwania mogłyby być takie same? Czy sa jakieś uprawnienia, które nam przysługuja, ale które też zarazem my musimy respektować w odniesieniu do innych ludzi, uprawnienia obowiązujące niezależnie od tego, gdzie żyjemy, kim są nasi rodzice, z jakiego pochodzimy środowiska itp.? Uprawnienia, które my mamy i inni powinni je respektować - wszelko pojawia się pytanie o to, czy każdy musi ich przestrzegać? Tak się zastanawiając, dochodzimy do pewnych uprawnień, które nazywaja się prawami człowieka, które dotyczą wszystkich, którzy są ludźmi, z uwagi na ich przyrodzona godność, zatem niezależnie od wszelkich możliwych podziałów i granic. Coś takiego, o czym myślimy, że jest takie ważne i niezbywalne, bo jesteśmy ludźmi, że nie można tego zabrać, coś, co musi być zagwarantowane - to są prawa człowieka.

Zanim oddam głos, pozwolę sobie wagę problemu zilustrować historia pochodzacca z pewnego serwisu internetowego. Niedawno Angelina Jolie przekazała znaczną sumę pieniędzy pewnej kilkunastoletniej dziewczynce z Pakistanu, która chciała kontynuować naukę. Za to, że chciała się dalej uczyć, a nie pracować i zakładać rodzinę w młodym wieku - dziewczynka została pobita. Pojawia się więc pytanie: czy to po prostu szczęście, że niektórzy urodzili się w Polsce, jak Państwo, mają więc sporo możliwości do wyboru, mogą na przykład kontynuować naukę, czy raczej wszyscy mają lub powinni mieć takie uprawnienia - do nauki i uczestniczenia w kulturze? Czy nauka i możliwość uczestniczenia w kulturze to kwestia tak zwanego fuksa, czy też praw, z których można zgodnie $\mathrm{z}$ własną wola korzystać? Jak to jest, a jak powinno być? 
Dr Krzysztof Przybyszewski

Postaram się ujać problem w kwestii pragmatycznej: prawa człowieka stanowią naszą drogę sprzeciwu wobec władzy. Ja sam posiadam władzę panowania nad studentami, egzekwowania pewnych rzeczy od studentów, czasami władzy tej nadużywam, a wtedy, gdy jej nadużywam, jestem przekonany, że czynię to słusznie w imię dobra wyższego. I nie wierzę, że istnieje człowiek, któremu nie zdarzyło się nadużyć władzy, jaką posiada, by pójść na skróty w osiagnięciu wyobrażonego przez siebie dobra wyższego. Czasami ten, kto twierdzi, że stan rzeczy powinien być inny niż jest i uważa go za niepożądany, a przy tym posiada pewną władzę, by wpłynąć w taki czy inny sposób na zmianę tego stanu rzeczy, posiada też tendencję do nadużywania swojej władzy.

Weźmy taki przykład: idą Państwo do sklepu i dzwoni bramka elektroniczna. Podchodzi strażnik i prosi o otwarcie torby. Sam jednak dźwięk bramki nie daje strażnikowi uprawnień, aby mógł przeszukać naszą torbę, ale gdy już dojdzie do przeszukania na policji, wtedy zwykle mówi się, że grzecznie poproszono nas o poddanie się przeszukaniu, a my się na to dobrowolnie zgodziliśmy. Niektórzy z Was są studentami, inni niedługo będa. Będziecie organizować różne imprezy, Waszym sąsiadom może to nie odpowiadać, mogą zadzwonić na policję. Prawa człowieka dają nam możliwość powiedzieć „nie, dziękuje”, „pan nie ma prawa wchodzić do mojego domu, co najwyżej może pan wezwać policje”. Policja zaś jeśli przyjedzie, a w moim domu nie miało miejsca żadne przestępstwo, ani nie doszło do żadnego zagrożenia życia czy zdrowia, lecz miało miejsce jedynie zakłócenie dobrosasiedzkiego współżycia, to taki patrol policyjny, jeśli nie otworzymy przed nimi drzwi, niewiele w rzeczywistości może zrobić, jak tylko spisać notatkę służbową o zakłóceniu ciszy nocnej. Wtedy możemy oczekiwać wezwania na komisariat, ale znowu: jeśli w naszym domu nie stwierdzono, że miało miejsce jakiejkolwiek przestępstwo, a takim nie jest zakłócenie ciszy nocnej, to nie mamy obowiązku udzielania informacji, o tym, czy byliśmy w tym czasie w domu, ani o tym, kto wówczas w nim przebywał, etc. W takim razie znowu policja ma związane ręce, pozostaje jej jedynie pouczyć nas o tym, byśmy szanowali swoich sasiadów i więcej już nie zakłócali ciszy nocnej. 


\section{0 | Debata |}

Gdyby jednak patrol policji próbował wtargnąć do Waszego domu bez Waszego pozwolenia, tylko z uwagi na zakłócenie ciszy, to na drodze sądowej możecie domagać się odszkodowania, ponieważ zostały złamane Wasze prawa, a dokładniej rzecz ujmując - Wasze prawa obywatelskie, które czasami stanowią broń przeciw tym, którzy nadużywają swojej władzy.

\section{Dr Andrzej W. Nowak}

Ja skomplikuję trochę odpowiedź na pytanie „po co nam prawa człowieka?” Co oznacza owo „nam” zawarte w pytaniu, kim jesteśmy „my”?

Mnie intryguje to, że właśnie „dla nas” prawa człowieka czasem sa niewygodne. Rewolucja Francuska była impulsem wolnościowym, pokazała, że prawa mogą dotyczyć ludu, a nie tylko arystokracji. Szybko okazało się to niewygodne dla Francuzów. To w imię ideałów Rewolucji Francuskiej, mieszkańcy Haiti zażądali zniesienia niewolnictwa i wzniecili pierwszą w dziejach świata rewolucję w imię praw człowieka. Francuzi odpowiedzieli przemoca, starając się krwawo zdławić ten wolnościowy zryw. Jak pamiętamy choćby z „Popiołów", także Polacy mieli w tym wydarzeniu swój niechlubny udział. Widać na tym przykładzie, że prawa człowieka moga być trochę niewygodne. Nasze samopoczucie w Polsce może się bardzo zepsuć, jeśli przyjrzymy się, ile w istocie znaczą prawa człowieka w naszym państwie, skoro państwo to ciagle przegrywa sprawy przed Trybunałem Strasburskim; nie radzimy sobie z niczym, z prawami obcokrajowców, z przestrzeganiem praw mniejszości, a także z długością postępowania sądowego czy nadmiernym stosowaniem aresztów. Zastanawianie się nad prawami człowieka to też pytanie o Nas, których te prawa dotyczą. Jeśli to przemyślimy, to uniwersalność praw człowieka okazuje się czasami niewygodna i może się okazać, że sami nadużyliśmy tych praw.

\section{Pytanie nr 2}

\section{Czy wolność jako taka rzeczywiście istnieje?}

\section{Dr Krzysztof Przybyszewski}

Jeśli chodzi o prawa człowieka, to liberałowie powiedza, że prawa człowieka opierają się na wolności, wtedy mówimy 
o „wolności od”. Pytanie brzmi: gdzie leży granica, tj. kiedy wkraczanie w życie jednostki jest bezprawne? Zakres wolności wyznacza autonomię jednostki, a nie autonomię działania. Główny temat naszego dzisiejszego panelu „Po co nam prawa człowieka?” porusza Leszek Kołakowski, według niego język praw człowieka jest nieprecyzyjny, niejednoznaczny. On chciałby go zastapić językiem obowiązku. Istnieje również „wolność do”, jest to bardziej kwestia wartości, jaka jest równość, a nie wartosci, która jest wolność. Wyróżniamy wtedy takie prawa, jak np.: prawo do opieki zdrowotnej prawo do pracy, prawo do odpoczynku; prawo do rzetelnego procesu sądowego. Wolność „od” i wolność „do” ukazuje prastary dylemat filozoficzny, czyli zachodzący konflikt między równością a wolnościa, który oznacza, że im więcej wolności, tym mniej równości, albo im więcej równości, tym mniej wolności. Powstaje dylemat, którą relację wybrać, jeśli wybieramy tę pierwsza, czyli więcej wolności a mniej równości, to przyjęta koncepcja praw człowieka będzie bliższa ujęciu liberalnemu, zaś gdy druga, czyli więcej równości a mniej wolności, to przyjęta koncepcja praw człowieka będzie bliższa ujęciu socjalistycznemu. Trzeba sobie również uzmysłowić fakt, że gdy mowa jest o prawach człowieka, to koniecznym jest odróżnienie dwóch pojęć: wolności i swobody, wolność nie sprowadza się do bycia swobodnym w swym działaniu.

\section{Dr Karolina M. Cern}

Zgadzam się z moim przedmówca. Pojęcie wolności jest różne od pojęcia swobody. W filozoficznym ujęciu, wolność jako idea jest zrozumiała dla człowieka właśnie. Wolność nie polega bynajmniej na tym, że mogę zabrać koleżance zegarek, obciąć jej włosy bez pytania. Istotą wolności jest to, że się rozumie wolność o tyle, o ile rozumie się i przestrzega wolności innych. Wolność związana jest z zasadą wzajemności, z tym, by taką samą wolność drugiej osoby, jaką my mamy, respektować.

Druga rzecz, to kwestia uprawnień oraz skorelowanych z nimi obowiązków. Idea praw człowieka to idea tego, co normatywnie pierwotniejsze jest od kategorii państwa. Zatem prawa człowieka - indywidualne uprawnienia - o ile maja być respektowane, generują pewne obowiązi nakładane na instytucje, w tym na poszczególne państwa. Zadaniem 


\section{2| Debata |}

władzy jest więc, między innymi, takie tworzenie oraz interpretowanie prawa, by to prawo - i konsekwentnie, nasz sposób życia - dostosowywać odpowiednio do wymogów zawartych w prawach człowieka. Innymi słowy, trzeba przypilnować, by ktoś naszą wolność szanował - to zadanie władzy wynikające z tego, że my jesteśmy wolni, „mamy wolność" i odpowiednie doń uprawnienia, ale też zadanie dla nas, dla każdego z nas.

Kolejna kwestia to druga generacja praw człowieka, w tym prawa socjalne. Otóż możemy sobie mówić, że jesteśmy wolni, bo nikt fizycznie na nas nie nastaje. Ale problem polega na tym, że nie trzeba drugiego do niczego fizycznie zmuszać, by naruszać jego czy jej wolność. Oto przykład. Załóżmy, że mieszkamy na bezludnej wyspie. Nasz kolega, który z nami tam przebywa, jest głodny, podczas gdy my mamy jedzenia w bród. Więc mówimy mu, że może dla nas pracować za miskę ryżu dziennie. On nam na to odpowiada, że przecież miska ryżu nie wystarczy mu do przeżycia. My zaś puentujemy rozmowę stwierdzeniem, że jest wolny i może pracować lub nie, wszak nikt go do tej pracy nie zmusza. I tutaj pojawia się pytanie: czy to jest rzeczywista wolność czy tylko taka iluzoryczna? Przecież on nie musi pracować - ponoć jest wolny.

\section{Pytanie nr 3}

Rodzice i społeczeństwo stale od nas czegoś wymagają. Czy te wymogi to nasze obowiązki, czy nie są one naruszeniem naszych praw? Do czego prawo mają rodzice, a do czego ich dzieci?

\section{Dr Krzysztof Przybyszewski}

W stosunku do dzieci mówi się nie tyle o prawach człowieka, co o prawach dziecka. Rodzice maja prawo wychowywać dzieci według własnego światopoglądu. Może zdarzyć się, że rodzice przekraczaja granice przymusu i dochodzi do łamania praw dziecka, i dlatego ważne było w Polsce rozróżnienie roli rzecznika praw dziecka od roli, którą pełni rzecznik praw obywatela. Powstaje na przykład pytanie i zarazem dylemat moralny i prawny, kiedy dziecko ma prawo powiedzieć dość wprowadzanemu światopoglądowi i religii przez rodziców. Czy państwo może w takim konflikcie reagować, przejmując w pewnym sensie rolę rodzica. Są to pytania i dylematy 
niezwykle trudne do rozwiązania. Tam, gdzie prawa człowieka maja charakter uprawnień, sytuuje to nas w sferze wolności, i by ją zabezpieczyć, formułuje się je w języku praw, a więc mamy na przykład prawo do prywatności, prawo wolności myśli, sumienia i wyznania. To jest właśnie wspomniana wcześniej wolność „od”. Natomiast tam, gdzie mamy wolność „do”, czyli występujemy z roszczeniem do spełnienia wobec nas czegoś, to wówczas pojawia się obowiązek, czyli muszą istnieć podmioty, które są odpowiedzialne za zrealizowanie uprawnionego roszczenia. Takim roszczeniem może być prawo do edukacji, a więc to rodzice i państwo mają obowiązek umożliwić nam edukowanie się na pewnym poziomie, który już indywidualnie ustalany jest przez konkretne państwa. Jeszcze inaczej, tam gdzie prawa człowieka przybieraja postać praw obywatelskich, bardzo często występuje problem podmiotu zobowiązanego coś komuś zapewnić.

\section{Pytanie nr 4}

Czy jeśli na youtube jest umieszczony filmik, który jest on dostępny np. dla USA albo dla większości państw, a dla Polski lub jakiegokolwiek innego państwa już nie, to czy jest to lamanie praw człowieka?

\section{Dr Krzysztof Przybyszewski}

Z USA jest problem, ponieważ państwo to pretenduje do tego, żeby być obrońca praw człowieka, ale nie podpisało żadnego dokumentu dotyczacego praw człowieka i nie odpowiada przed międzynarodowym trybunałem karnym. Co oczywiście nie oznacza, że skoro USA dokumentu takiego nie podpisało, a Polska podpisała, to u nas prawa nie sa łamane, a Stanach Zjednoczonych sa.

\section{Dr Piotr W. Juchacz}

Myślę, że w pytaniu chodzi o to, że np. Chiny, cenzurując dany filmik, moga łamać prawa człowieka, a konkretnie prawo do swobodnego dostępu do informacji.

\section{Dr Krzysztof Przybyszewski}

Ogólnikowo można powiedzieć tak: prawo dostępu do informacji zostało złamane, jeśli film zawiera prostą treść, np. prezentuje śpiew podczas uroczystości rodzinnej, czy też muzykę 


\section{Debata |}

(o ile prawa autorskie sa zachowane). W tym kontekście rozważyć trzeba perspektywę konkretnych informacji. Na przykład, jeśli jest to kwestia tajemnicy państwowej, to wtedy mówimy o ograniczonym przepływie informacji, a więc jeśli jest to filmik prezentujący rozmieszczenie jednostek wojskowych, baz wojskowych wraz z ich wyposażeniem, to trudno mówić wówczas o złamaniu prawa do informacji, bowiem państwo realizuje w ten sposób swoje zadania, jakim jest zapewnienie bezpieczeństwa wewnętrznego i zewnętrznego.

\section{Dr Andrzej W. Nowak}

Prawa człowieka maja pewien problem z kapitalizmem. Gdy wchodzimy do Internetu i tam jest blokada oglądania pewnych treści, pojawia się problem, jak walczyć z taką cenzura. Prawa człowieka nie moga regulować takiej cenzury; a mimo to nie możemy czegoś gdzieś zobaczyć. Łatwo krytykować z perspektywy praw człowieka cenzurę państwowa, polityczna, Ale co rynkiem, z Internetem? Wojciech Orliński napisał o tym artykuł, i paradoksalnie, w Internecie był on dostępny jedynie we fragmencie, za całość trzeba zapłacić. My tak naprawdę nie mamy kontroli na portalach społecznościowych, tam możemy za to być kontrolowani przez korporacje, często intensywniej niż przez dawne totalitarne państwa. Ktoś zdecydował, że nie możemy pewnych rzeczy obejrzeć. Jest to łamanie naszych praw, ale jest trudne do zdefiniowania jako łamanie praw człowieka.

\section{Pytanie nr 5}

\section{Czy w Polsce są respektowane wszystkie dokumenty dotyczące praw człowieka?}

\section{Dr Krzysztof Przybyszewski}

Tych dokumentów jest naprawdę dużo, o różnej wadze i znaczeniu. Ostatnimi czasy Polska miała problemy z ratyfikowaniem Konwencji Bioetycznej, dopóki nie ratyfikowano tego dokumentu, to w Polsce teoretycznie można było sklonować człowieka. Na dzień dzisiejszy można powiedzieć, że ratyfikowaliśmy te najważniejsze dokumenty. Co nie oznacza, że stan praw człowieka w Polsce jest satysfakcjonujacy, bo co innego stan prawny, a co innego stan rzeczywisty. Polska cały czas nie radzi sobie ze zbyt przewlekłymi 
procesami sądowymi, czyli nie realizuje w sposób zadawalający prawa do rzetelnego procesu sądowego, za co musi czasami płacić olbrzymie odszkodowania osobom, wobec których nie zrealizowano tego prawa. Bo procesy sądowe powinny być rozstrzygnięte $\mathrm{w}$ stosownym terminie, a czasem zdarza się tak, że ludzie nie dożywają końca własnego procesu.

\section{Pytanie nr 6}

Czy może być tak, że prawa człowieka są tworzone w obrębie jednej kultury i narzucane innym kulturom, i czy nie jest to lamanie praw człowieka w innych kulturach?

\section{Dr Andrzej W. Nowak}

Jest to problem, bo pytanie nawiązuje do genezy praw człowieka. Prawa człowieka sa historycznie związane z kultura europejska, po II wojnie światowej prawa człowieka były konsensusem ustanowionym przez niewielka liczbę państw. Większość krajów świata była wówczas skolonizowana. Należy pamiętać jednak, że tak jak pokazałem na przykładzie Haiti, dochodzi do uniwersalizacji. Haitańczycy walczyli w imię praw człowieka z europejską Francją. W imię praw człowieka i idei samostanowienia się ludów skolonizowane kraje wyzwalały się spod europejskiej dominacji. Podstawowe pytanie dotyczy trzeciej generacji praw człówieka, na ile mam prawo być innym, na ile pomaga mi w tym moja wolność? Na ile mam prawo do własnej tożsamości, do jedzenia tego, co chcę, do własnych obyczajów? „Różnica” to pojęcie kluczowe dla trzeciej generacji praw człowieka, dla pierwszej generacji kluczowa była wolność, dla drugiej z kolei równość. Jak pogodzić te trzy generacje? Michel Novak pokazywał, że wymóg asymilacyjny, uzyskanie obywatelstwa USA, wymagało od imigrantów pokonania siedmiu przeszkód, złamania siedmiu pieczęci. Aby zostać Amerykaninem, chłopski imigrant z Polski musiał m.in. nauczyć się myśleć o sobie tylko w kategoriach indywiduum, być egoista, przestać orientować się na rodzinę. To może być poważnym problemem. Pamiętam jak raz na Sycylii widziałem kierowcę publicznego autobusu, który zatrzymał się tylko po to, aby porozmawiać z wujkiem. Zawarta w prawach idea jednostki, może być w kolizji ze wspólnotowymi, 
116 | Debata |

rodzinnymi wartościami. Czy ów kierowca złamał kontrakt, jaki zawarł z pasażerami (na świadczenie usługi), czy był wierny swojej wspólnocie rodzinnej?

Istnieje podstawowy problem w tym, jak pogodzić asymilacyjny aspekt praw człowieka; jednostka i jej prawa może być w konflikcie z ważnymi dla nas wspólnotowo wartościami. Na pewno pamiętacie o publicznym zakazie noszenia chust muzułmańskich we Francji. Wprowadzono go w imię wartości świeckiego państwa. Z kolei znam przypadek, gdy na uniwersytecie marokańskim walczono o prawo do noszenia chust, sprzeciwiając się francuskiej kulturze politycznej. Pikanterii dodaje fakt, że to dziewczyna walczyła o prawo do noszenia chusty w kraju muzułmańskim.

\section{Dr Krzysztof Przybyszewski}

Potrafię podać łatwą odpowiedź na to pytanie. Mogą być różne koncepcje praw człowieka, mamy np. islamska deklarację praw człowieka. Właściwie wszystkie państwa mówią językiem praw człowieka, różnica polega na ich konceptualizacji. Warto przytoczyć przykład ze studnia, do której wpadło dziecko: na pytanie, kto jest temu winien, w różnych kulturach odzielano różnych odpowiedzi, a to że rodzice, a to że konstruktor. Zawsze jednak zadawano pytanie, kto jest za to odpowiedzialny. We wszystkich kulturach uznaje się zatem, że dziecko ma prawo do ochrony, do opieki. Jest to prawo uniwersalne. To, że natomiast w Chinach odpowiedzialność za krzywdę dziecka poniesie konstruktor studni, a w USA rodzice, oznacza, że akcenty związane z pojęciem odpowiedzialności za respektowanie tego prawa, moga być inaczej rozłożone.

\section{Pytanie nr 7}

Czy musimy ustanawiać konkretne reguły? Tzn. skoro wiemy, że powinniśmy się w określony sposób zachowywać, to po co nam ustanawianie konkretnych regul, skoro i tak wszyscy wiedzą, jak się zachować?

\section{Dr Karolina M. Cern}

Być może wniosek płynący z tego spostrzeżenia jest właśnie odwrotny? To znaczy, my ludzie, czasem jesteśmy zdolni do niegodziwości i dlatego staramy się zapewnić sobie 
nawzajem, kooperacyjnie, pewną ochronę przed tą niegodziwościa, która chociaż czasami, to jednak ma miejsce. W ideę praw człowieka wpisane jest roszczenie uniwersalistyczne, co oznacza, że ludzie sami starają się myśleć w pewnych kategoriach wykraczających poza ochronę ich - tylko ich - interesu własnego. Ale co jest interesem własnym, a co dobrem każdego i dlatego wszystkim powinno być zagwarantowane, to nie jest „od razu” czy „z góry” jasne, gdyż żyjemy w skomplikowanym i zmieniającym się świecie, który jest przez nas komunikacyjnie wytwarzany od dobrych kilku tysięcy lat. Istnieją różne religie, różne kultury, różne wzorce zachowania aprobowanego przez bliższe bądź dalsze otoczenie. Dlatego prawa człowieka sa polityczno-prawnie konstruowane w zgodzie z obecnie dostępnymi nam moralnymi uzasadnieniami, a nie rekonstruowane na podstawie badań nad natura ludzka.

Ujmując rzecz obrazowo - jak onegdaj powiadał mój kolega, mamy przed sobą kufel piwa, o którym możemy powiedzieć, że jest do połowy pusty, lub że jest do połowy pełen. Mnie się wydaje, że ta druga interpretacja jest w tym przypadku trafniejsza. Jeśli bowiem obserwujemy szeroko zakrojoną i intensywną mobilizację ludzi do działania na rzecz respektowania praw człowieka, to znaczy, że jest to dla nich sprawa dużej wagi. Ta mobilizacja implikuje nie tylko wzniosłe wzajemne rozmowy, lecz również adresowanie konkretnych oczekiwań do określonych instytucji oraz egzekwowanie od nich sprawnego realizowania tych praw. Niewatpliwie istnieją ludzie niezainteresowani z różnych względów przestrzeganiem tych praw, ale dzięki instytucjonalizacji tych praw - czyli prawnopolitycznemu ich zabezpieczeniu - zyskujemy narzędzie do ochrony przed tymi ludźmi oraz przed instytucjami, w ramach których prowadzą swoje działania.

Poza tym, powtarzam, świat jest bardzo różnorodny, ludzie w tym świecie są przeróżni i wielokroć odmiennie widzimy, rozumiemy rozmaite, dla nas ważne sprawy. Idea praw człowieka, to jednak idea tego, co wspólne nam wszystkim, gdyż ważne dla każdego z nas. Być może jest tak, że niektórzy z natury nie są źli, ale zostali pewnych haniebnych działań nauczeni. Czy małe dzieci z egzotycznych dla nas plemion, które biegają z bronią i strzelają do ludzi, sa z natury złe? Broń jest wytworem ludzi, a tym dzieciom przyszło żyć w świecie, którego nie tylko nie znamy, 


\section{8 | Debata |}

ale też najprawdopodobniej nie chcielibyśmy znać. Prawa człowieka sa forma obrony przed takimi ludzkimi wytworami jak niewola, zniewolenie, upokorzenie czy zależność.

\section{Dr Piotr W. Juchacz}

Filozofowie pisali, że ludzie z natury nie są aniołami i człowiek często jest nastawiony na realizację partykularnego interesu. Warto przytoczyć tutaj stanowisko Davida Hume'a, jednego z najwybitniejszych przedstawicieli szkockiego oświecenia (XVIII wiek): wyobraźmy sobie dwie sytuacje - powiada Hume - jedna jest taka, że mamy do czynienia z nadmiarem wszelkich dóbr, weźmy za przykład powietrze, którym możemy wszyscy oddychać i nie musimy go dzielić; jeśli byłoby tak z wszystkimi dobrami, to wszystkie reguły podziału dóbr, czyli reguły sprawiedliwości, nie byłyby ludziom potrzebne. A teraz wyobraźmy sobie sytuację drastycznie przeciwstawną: gdy mamy do czynienia z skrajnym niedoborem dóbr, czyli ludzie, by przeżyć, muszą walczyć na śmierć i życie z innymi, a przegrani umierają z głodu, chłodu i wycieńczenia. I w takiej sytuacji, kontynuuje Hume, prawa nie byłyby ludziom potrzebne, ponieważ w tak skrajnym położeniu ich wprowadzenie nie miałoby sensu, gdyż nie mogłoby doprowadzić do sprawiedliwego podziału dóbr. Tylko w sytuacji, z jaka mamy do czynienia zazwyczaj, a więc umiarkowanego niedoboru dóbr, wprowadzenie zasad sprawiedliwości ma sens i jako takie jest prze ludzi postrzegane. Albowiem pomimo iż ludzie dążą do realizacji partykularnych interesów, to cechuje ich również ograniczona wspaniałomyślność, która pozwala im dostrzec, że wzajemna kooperacja pomaga budować społeczeństwo, w którym będą mogli rozwijać się lepiej. Dlatego wolą wyjść z pierwotnego stanu natury i poprzez akt umowy społecznej dotyczącej ustanowienia praw, które będą ich wszystkich odtąd obowiązywały, razem tworzą społeczność z wybranymi władzami, których zadaniem jest pilnowanie przestrzegania tychże postanowień.

\section{Dr Andrzej W. Nowak}

Ja odpowiem trochę anegdotycznie. Chętnie bym się pozbył praw człowieka, gdyby było możliwe zostać w takim świecie, w jakim żyli Hobbici u Tolkiena. Jak pamiętacie w tym błogim obrazie byli strażnicy, którzy chronili Idylle 
i gdyby takie Idylle istniały, to byłoby świetnie, ale tak nie jest. Społeczeństwa stają coraz większe, jakbyśmy bardzo nie byli przywiązani do sielankowych wizji rodzinnych, wspólnotowych, nie da się naszych problemów życiowych rozwiązać w ten sposób. Musimy mieć jakieś urządzenia społeczne, państwa, które sa ponad jednostka, wspólnotą i ich interesami. Nawet gdybyśmy bardzo chcieli żyć indywidualistyczne, to nie da się wszystkich naszych problemów życiowych rozwiazać i dlatego musimy mieć państwo lub jego odpowiedniki. A jak ono się pojawia, to mamy problem władzy, z którym trzeba coś zrobić. Gdy czyta się preambułę praw człowieka, to widać, że jest ona pisana językiem warunkowym. Jest pisana tak, że gdyby nie było złych doświadczeń, nie musielibyśmy mieć tych wszystkich praw. Ale zważywszy na przeszłe doświadczenia (koszmar II wojny światowej i Shoah), prawa człowieka warto przyjaćc. Gdyby nie było tych doświadczeń, nie musielibyśmy mieć takich praw. Byłoby miło, gdybyśmy w przyszłości nie dawali sobie już więcej powodów do tworzenia praw człowieka.

\section{Pytanie nr 8}

Żyjemy w państwie demokratycznym, w którym liczy się wola większości obywateli. Jednakże wiemy, że obowiązkiem większości jest również dbanie o prawa mniejszości. Stąd pytanie, czy nie było złamaniem praw człowieka odrzucenie w Polsce ustawy o związkach partnerskich?

\section{Dr Krzysztof Przybyszewski}

Dla mnie to bardzo skomplikowany problem. Zarzuty w stosunku do praw człowieka to studnia bez dna. Prawa człowieka wyznaczają zależność miedzy państwem a jednostka. I jeśli chodzi o związki partnerskie, to oczywiście kwestie te dotykaja praw człowieka, bo wprowadzanie ograniczeń w tej sferze życia uniemożliwia ludziom życie według własnych poglądów i własnej filozofii. I to też jest problem demokracji, gdy nie gwarantuje ona realizacji praw człowieka. Nie ma zresztą takiego ustroju, który by je w pełni gwarantował, możemy powiedzieć, że w każdych ustrojach łamie się prawa człowieka. To, że mamy demokrację, nie znaczy, że nie są w niej łamane prawa człowieka, ponieważ tam 


\section{0 | Debata |}

gdzie jest władza, tam prawa człowieka łamane są zawsze. Prawa człowieka maja charakter dynamiczny, również one podlegają ograniczaniu i zawieszaniu. Jednakże nasza przewaga polega na tym, że żyjąc w systemie demokratycznym, mamy narzędzia ku temu, aby walczyć o własne prawa. My jesteśmy nośnikami tych praw, te prawa są w nas i możemy o nie walczyć.

\section{Dr Piotr W. Juchacz}

Jeśli przyjrzymy się badaniom sondażowym, to możemy zaobserwować, że akceptacja dla związków partnerskich z biegiem lat zwiększa się na ich na korzyść.

\section{Pytanie nr 9}

Gdy ktoś idzie do więzienia, przyjmuje się, że ma prawo godnie żyć, więc państwo daje pieniądze na jego utrzymanie. Czy jest to jednak sprawiedliwe? Przecież te pieniądze można by przeznaczyć na kogoś innego, czlowieka w potrzebie.

\section{Dr Krzysztof Przybyszewski}

Mamy godność osobową i osobista. Osobowa znaczy, że jesteśmy ludźmi i z tego powodu należy nam się szacunek. Osobista jest związana z wolnością osobista. Warto przytoczyć tutaj następujaccy przykład. Kapitan statku ma ze względu na swoją rolę społeczną obowiązek opuścić statek jako ostatni, ale też nie przestaje być człowiekiem, który ma prawo walczyć o swoje życie. Można go więc oskarżyć, wysłać do więzienia, bo naruszył obowiązki wynikające z roli społecznej, ale nie można odbierać mu godności, bo nie przestaje być osoba. Mimo że sprzeciwił się roli społecznej, to my mamy nadal obowiązek postępować wobec niego w duchu braterstwa.

\section{Dr Piotr W. Juchacz}

Dziękuję wszystkim Państwu za udział w naszej debacie. Jako organizatorzy niniejszego spotkania postanowiliśmy osobom aktywnie bioracym udział w dyskusji podarować pierwszy i drugi numer założonego przez nas i wydawanego w Instytucie Filozofii UAM czasopisma Filozofia Publiczna i Edukacja Demokratyczna. Raz jeszcze dziękuję serdecznie za przybycie i wspólną dyskusję. 